ROCZNIKI KULTUROZNAWCZE

Tom X, numer $4 \quad-\quad 2019$

DOI: http://dx.doi.org/10.18290/rkult.2019.10.4-7

DANIEL FITZPATRICK

\title{
BELLOWS IN MALAGA: THOMISTIC INSIGHTS VIA PABLO PICASSO
}

\author{
PROLOGUE: BY WAY OF PIGEONS
}

In one of Assisi's many narrow stairs, as we passed level with residents' roofs from one millenarian piazza to another, my friend paused, eased a camera from a pocket, and directed its lens to a pair of pigeons perched upon the roofing tile. The rest of us, nineteen or twenty and bent on discovery of the great historical sites, stared. "Just a second," my friend whispered. "It's been a lifelong love affair." One of us laughed, and the pigeons burst into the applause of their takeoff, wheeling a moment in the bright Umbrian sun and dipping toward one of the countless quietudes around.

I have been reminded frequently of this episode on a recent reading of John Richardson's biography of Picasso, whose father made endless portraits of the pigeons of Malaga and who throughout his career made artistic reference to this thematic patrimony. Such Columbid obsessions leave us at first perplexed. For who could love the pigeon pecking in the gutter, distasteful as a rat? Or who, aiming for artistic greatness, could attach his aspirations to the lowly rock dove?

Yet who, spending more than a moment's glance, has observed the royal iridescence of the pigeon's neck without admiration? There is, too, a childlike delight in the birds of Trafalgar Square and a romantic quickening of appetite in the thought of pigeon pie. Further off, we remember Theodore Roosevelt and the last confirmed sighting of the passenger pigeon. In the pi-

DANiEl FitzPATRICK - Holy Apostles College and Seminary Cromwell, Connecticut, USA; address for correspondence — e-mail: dfitzpatrick@holyapostles.edu. ORCID: https://orcid.org/ 0000-0001-6751-4207. 
geon, in short, lies at once those things nearest to us and those most distant from our minds. It is there on the sidewalk and there, too, passing out of existence, eternal in the human round of life and gone in the blink of the cosmic eye.

This is to say that the pigeon falls within the genus of human being (not, of course, human being as an animal species but human being as the kind of being typical of man). And if the task of the artist is in some way to organize the elements of sense experience so as to please his audience, then it is not so absurd to consider the pigeon, touching as it does on so many areas of human life, a worthy subject of art.

Here, though, we draw only such obscure conclusions as might provide grounds to begin a clear study. To that end, let us propose a meeting of minds. One, Picasso, emblem of modern art, has been mentioned, and we wish to explore his work further in light of the thought of St. Thomas. To do this, we shall first need a clear understanding of St. Thomas's teaching on the problem of the one and the many, and here we must answer three questions:

(1) What is a genus?

(2) How are genera organized according to contrary opposition, and what role does virtual quantity play in such organization?

(3) How do a knower and the thing known constitute opposite poles of a genus?

With these answers firmly in hand, we might then turn to an analysis of art, with particular reference to Picasso, with a view to clarifying three complementary points:

(1) How the artist and his work constitute a genus, and how the work of art and the viewer constitute a genus;

(2) How the work of art affirms the generic relation of sense object and sensate being;

(3) How the artist subordinates the practical to the speculative in his work and what this implies for the role of the artist in an increasingly practical age.

This accomplished, we will conclude with a Thomistic analysis of certain of Picasso's works, considering how they create generic organizations among the subject, Picasso, and us as viewers, how they blend the speculative and the practical in art, and what Picasso's art indicates for man's place within the entire genus of being. 


\section{AQUINAS, THE PROBLEM \\ OF THE ONE AND THE MANY, AND GENUS}

In format and flavor Aquinas often seems as far from his ancient forebears as he in fact was in time. Certainly his first point of departure must be in Revelation rather than reason alone, and in this his work is alien to the ancients, or separated at least from theirs as by a veil and a doxological cloud. Nonetheless, his mind seems frequently to run as smoothly on from the point where Plato or Aristotle left off that but for style he could have strode directly from the Lyceum to the Sorbonne. As background to much of his work we find the same problem which so fascinated the ancients: that of the one and the many. The ancient Greeks, gazing out on the Aegean's opalescent blue water wreathed in cloud and studded with stone, sea urchin, and fish, sought to explain how such multiplicity could exist in a unified world. How, for instance, can we explain the composition of a cloud or of the sea? And how can the two, if they share components, be separate? Several proposed that all things were unified by some underlying matter, such as water, while others, with a touch more sophistication, proposed an undefined substance or apeiron as basis for all defined substances.

Plato, of course, proceeded to his split-realm vision of the universe, with the multiple material things here below participating in the single, unified forms above. This solution, rather breath-taking in its scope as well as in its ability to address certain fundamental aspirations of the human spirit, nonetheless presents a host of difficulties. How, for instance, can the Forms inform the things of the material realm? And how might we account for the individuality of each participant in a Form which is entirely whole on its own?

Aristotle, acme of the ancients, responds to Plato's upward gaze with one turned squarely upon the world around him. In his solution to the problem of the many we find much of the basis for Aquinas' work. And this solution lies primarily in the notion of substance or genus, a notion which requires careful unpacking, first of all because the Latinate roots of the word substance (to stand beneath) might lead us to the thought that substance is merely that which stands beneath a certain being and second of all because the term genus has come to be taken as a scientific category of beings.

For Aristotle and St. Thomas, however, we might most easily understand substance or genus by way of an organizational network. That is, a substance or genus is simply an organization consisting of parts who are directed toward an end by one highest part and who take their organization from con- 
trary opposition arising from their limited access to the organizational end. The military example lends itself most neatly to our purposes. Obviously an army has as its aim victory in battle. Yet an unorganized mass of men hurling itself blindly toward the intended victory can hardly be considered an army if it is not properly organized and directed to that end by a competent general. Spartan and Roman warfare made clear time and again that victory is not decided by numbers as much as it is by organization, processes, and direction. The great generals - the Alexanders, the Hannibals, the Caesars of the world - were great in virtue of their ability to see the end and to organize the resources at hand so as to achieve that end. And the commanding eye, in order to be successful, must be able to proceed along the lines of contrary opposition, not simply treating each soldier as equal but deploying, by way of his close subordinates, his cavalry, infantry, archers, etc., to the greatest possible effect.

\section{CONTRARIETY AND GENERIC ORGANIZATION}

This notion of contrary opposition, too, requires attention. When we consider opposition we tend to think first of contradiction, especially when we think of Aristotle, for whom the principle of non-contradiction played such an important role. Yet genera can only be organized according to contrariety, wherein differences are able to exist within an organization without causing it to disintegrate. That is, an army does not fall apart simply because it is composed of soldiers of various ranks who relate differently to the end of victory; rather, it can only exist in a proper sense if such differences exist. On the other hand, in those instances where contrariety does not attain, division will cause disintegration, as when two generals try to command the same army.

The same principles apply in all organizations, whether in athletic teams, businesses, or flocks of birds. A football organization, for instance, has a head coach who oversees the direction of the entire team. The head coach directs different elements of the team via coordinating coaches who specialize in a particular element of the head coach's overall vision. The players have individual tasks within those different elements overseen by the coordinators, and all the players on the field take direction most immediately from the quarterback. The organization functions according to this contrariety existing among the coaches and players in their various positions, and this 
contrariety arises from each member's proximity to the overall vision of the head coach. Problems arise, however, when contradictions occur. Should the fullback and the running back both attempt to take the handoff from the quarterback, nothing is more likely than a fumble. Should a wide receiver attempt to call the quarterback's audibles, the play is unlikely to succeed.

The same principles, moreover, apply to individual beings. For indeed, it is not only those organizations consisting of multiple individuals which ought to be called genera, but also individuals themselves according to their organization. Humans, for example, are composed of body and soul, with the soul as seat of emotion, imagination, passive and active intellect. We are directed toward an end - for St. Thomas, of course, perfect happiness in the Beatific Vision - by the soul, and it is this direction which organizes all of our subordinate faculties of intellect, imagination, and sense. Our happiness is most disturbed when those subordinate faculties hold undue sway over the rest. The overly emotional person, for instance, is often unable to respond physically and mentally to the task at hand. The overly sensual person, or the one who has been deprived of physical needs, distracted by food, drink, and sex, is unable to attend to the intellect. We remember, for example, Odysseus among the Phakians, unable to proceed as quickly as he would on his journey on account of the belly and its ravages. ${ }^{1}$ Again, the contrariety appropriate to a genus has been disrupted by contradiction, with one part seeking to take the place of the highest part and so breaking off the whole organization's attention to the end.

We see more of the same at the molecular level and at the cosmic level. Each molecule is organized according to its purpose, with its different atomic elements relating to each other according to their own characteristics. The whole of the universe is so organized, too, with God as the end of all being as well as the one who directs all being to himself, with all being falling into hierarchical place accordingly. Disruptions within the universe arise when constituents differing contrarily move to a stance of contradiction. Thus the fall of those angels who would not serve, and thus the fall of man in Satan's temptation to Adam and Eve to become as God.

Through all this we must remember the distinction Aristotle draws between dimensive and virtual quantity, for it is in large part this distinction which makes our understanding of contrary opposition possible. Dimensive quantity refers to physical amounts of being, as a seven-foot length of board

\footnotetext{
${ }^{1}$ Homer, The Odyssey, trans. Richmond Lattimore (Chicago: University of Chicago Press, 1965), VII, 215-221.
} 
or an eight-foot length of board. We have an amount of matter measured according to a kind of arbitrary least common denominator, the foot. Within the organization of the board it is the individual length of the foot which serves as measure of the whole. Dimensive quantities, likewise, exist in contradictory as well as contrary relationships. That is, two lengths of board cannot occupy the same physical space, though two lengths of board, arranged by the mind of the builder, may take contrary positions with respect to the overall aim of construction, just as two men in an army are arranged with respect to the general's strategy.

Virtual quantity, on the other hand, refers to the intensity of a thing's being. ${ }^{2}$ An eight-food board possesses no greater intensity of being than a seven-foot board. A general, however, by experience and organizational advancement ought to possess greater intensity of military greatness than a foot soldier. It is by this virtual quantum intensity that genera, including the entirety of being, from rocks through plants and animals up to man, the angels, and God, are hierarchically organized.

We see then that all genera are arranged - and function well - according to relationships of contrariety, whereas genera function poorly when contradictions occur. Plainly many genera, as the hierarchy of being, molecular structures, etc., arise naturally, out of the overall genus of being as it were. Others occur through the facility of human faculties, and it is to these we now turn our attention.

\section{KNOWER AND KNOWN AS GENERIC POLES}

Knowledge, Aristotle tells us, may be divided broadly into two kinds: practical and speculative. The former seeks to know something for the sake of some kind of production; the latter seeks to know something for the sake of the knowledge itself. Or, as St. Thomas puts it in his Commentary on Boethius' De Trinitate, "The theoretical or speculative intellect is properly distinguished from the operative or practical intellect by the fact that the speculative intellect has for its end the truth that it contemplates, while the practical intellect directs the truth under consideration to activity as to an end."

\footnotetext{
${ }^{2}$ Fran O'Rourke, Pseudo-Dionysius and the Metaphysics of Aquinas (Notre Dame, IN: University of Notre Dame Press, 2005), 157.

${ }^{3}$ Thomas Aquinas, Commentary on the De Trinitate of Boethius, trans. Fathers of the English Dominican Province (New York: Cosimo, 2007), q. 5 a.1.
} 
Consider, for example, the study of anatomy. A physician ought to understand the human anatomy in order to recognize disease by anatomical anomalies as well as to correct disease by restoration of proper anatomical activity. Likewise a sculptor or painter ought to understand human anatomy in order to convey the body realistically in his work or, if he departs from realism, in order to convey some reality beyond the physical one. One wonders, for instance, at Bernini's sculptures because they convey with such fine precision the form of man and woman - the texture of hair or the impression of a hand upon a thigh. Viewing Michelangelo's figures in the Sistine Chapel, on the other hand, one is often struck by the female figures' large, muscular arms and torsos, oddities which, if we are not to accuse the artist of poor vision, we might attribute to a classical predilection for the beauty of the masculine figure or as comment on the might of such women as the sibyls.

Speculative knowledge, on the other hand, seeks knowledge for its own sake, or at least for the sake of the kind of contemplative joy arising from an understanding of what something is or how something works. Much of the study of astrophysics aims at speculative knowledge, if only because much of the knowledge available about the stars can have, at least at present, little to no practical consequence. As St. Thomas continues, "the subject-matter of the speculative sciences must be things that cannot be made or done by us, so that our knowledge of them cannot be directed to activity as to an end." Rather, to understand the movement of the heavens is to satisfy one of the great wonders of the human heart. In philosophy, too, many disciplines aim at speculation rather than production. Epistemology and aesthetics, for instance, while they may have certain productive ends as in the development of educational or artistic programs, may also aim simply to satisfy human curiosity regarding the way we come to know things or the way that beauty strikes us.

In cases of both practical and speculative knowledge the knower and the thing known coalesce to form a genus. We recall, of course, that a genus is an organization directed toward an end by the highest member, with all subordinate parts distributed according to the contrariety of their degrees of possession of that end. The human mind thus functions as highest member of the knower-known genus by directing the knowledge toward the intended end. Let us return first to our physician. By studying the anatomy of particular human bodies as well as the generalizations of textbooks, he acquires a body of knowledge which is in turn directed to the treatment of ailing bod-

\footnotetext{
${ }^{4}$ Ibid.
} 
ies. At the same time, our physician likely became a physician in part due to wonder at the body, and so the knowledge he has acquired by long study serves also to satisfy and stimulate that wonder. We might then submit that if the knower-known organization has as its end something outside the knower, then we are dealing with practical knowledge, whereas if that end resides within the mind of the knower, then we are considering speculative knowledge. It is curious to note, too- and this will prove crucial for our understanding of the artistic method - that the knower-known genus, which takes its root in an internal-external polarity, slowly becomes internal to the knower. The physician derives his knowledge from external sources, that is, and the more intense his knowledge, the more internal it becomes.

We see this process of internalization, likewise, in the case of good cooks. One begins, often, by studying cookbooks or by watching relatives at work in the kitchen or celebrity chefs in the studio. At this point in the process we notice a twofold generic polarity. For the cookbook, taken from the mind of an experienced chef, as well as the relative or celebrity, has as its end the production of knowledge in the mind of the amateur. The amateur, on the other hand, gathers up knowledge for the sake of producing good food. The knowledge so gained slowly becomes internalized until the cook acts without external aids. Nonetheless, the cook's creative action utilizes those same exterior objects demanded by a recipe or a teacher. Where the recipe once listed such things as chicken, salt, pepper, flour, etc., the habituated mind now reaches for such things by second nature, drawing them into an organizational unity directed to the production of a delicious dish.

Let us turn now to Picasso, with a view to understanding his work in light of St. Thomas's teaching on generic unity and in turn to supplying a brief critique of the present state of art.

\section{THE EYE: PICASSO AND THE ORDER OF THINGS SEEN}

Perhaps it was the Impressionists and their near successors who proved that great painters need not be great draughtsmen. The eye sees more than lines, and the effects of dazzling color may in themselves suffice to validate a painter's vision. And, which is more, we see colors directly, whereas nowhere in nature do we see a line or curve as those we abstract for our theoretical purposes. Anyone lacking talent or teaching can attest to the difficulty of drawing, the execution of which requires not only the ability to see 
things as they are but also the skill to translate that sight by hand into its miniature on paper or canvas.

Picasso, we have seen, watched as a small child while his father painted the pigeons of Malaga. ${ }^{5}$ His father, a meager artist, nonetheless managed to support his family by a combination of familial charity and a series of teaching posts and curatorial positions in Malaga, Corunna, and Barcelona. Pablo thus, though often reluctantly, spent much of his youth in the tutelage of the Spanish academies, beginning with one of his father's own classes in ornamental drawing. ${ }^{6}$ The teaching, rarely great, nevertheless provided the young giant with a solid academic ground upon which he based his later art. The tradition of such great Spanish painters as Velasquez and El Greco, though diluted at the hands of mediocre instructors, impressed itself upon the young man's mind, and through them he became first and foremost an artist of great vision - not simply that vision by which an artist directs his work to an end but also that immediate vision whereby he sees the world around him accurately and thus gains material to direct to his artistic end.

We have seen that the knower and the thing known come together to constitute a genus. Likewise the artist and his subject constitute a genus, with the end being the work of art itself. The artist observes a dapple of light in a wood, a bull in the ring, a woman recumbent upon a bed, and produces a version of his observation in paint. All the details of the subject's appearance are filtered through the particularities of the artist's senses as well as his artistic sensibilities, with the obvious results that not only will different artists produce different artistic interpretations of the same subject but that the same artist will produce different versions of the same work according to changes in his artistic thinking, shifts in mood or temperament, or degree to which he considers the work at hand to correspond to the work as intended.

From this it becomes plain to see how it is that artists pass through different artistic phases. Picasso, of course, is famous for such periods as the Blue, Rose, and Cubist, periods which arose according to his temperament, palette, and philosophy. The Blue Period, for instance, grew out of a depressing stint in Paris in which Picasso's finances as well as mental and social health suffered. ${ }^{7}$ In such periods, the artist's work is directed not only to the particular end of each painting but also toward the general concretization of the artist's

\footnotetext{
${ }^{5}$ John Richardson, A Life of Picasso: The Prodigy, 1881-1906 (New York: Alfred A. Knopf, 2012), 13.

${ }^{6}$ Ibid., 45.

${ }^{7}$ Ibid., 251-67.
} 
consistent vision through time. In addition, then, to the generic organization of each painting, we see that broader genera emerge within an artist's œuvre.

Yet the organizing power of the artist's mind does not end entirely in the production of the painting. For genera would seem also to emerge among works of art and their viewers, with the experience of the beautiful as the end of the artwork-viewer organization. St. Thomas tells us that the "beautiful things are those which please when seen." ${ }^{8}$ More detailed explanations of beauty are possible, but St. Thomas's, as usual, gets to the root of common experience. For who has not had the experience of walking through a museum, happening upon an unfamiliar painting, and feeling pleasure? In that moment, a generic organization has arisen between the mind of the viewer and the work of art viewed.

The power of a particular artist, moreover, may be judged in part by the universality of his works' power to please apart from any explanation or demand. Just as a beauty queen demands the attention of all present simply by entering a room, a great work of art tends to draw the eyes of all who happen upon it. This makes all the more sense when we consider St. Thomas's teaching, following Aristotle, that the highest member of a genus is the measure of all the other members of that genus and that it is the one with the greatest virtual quantum intensity who accomplishes the most with the least effort or with the least multiplication of parts. Aristotle's Prime Mover, for example, does nothing, strictly speaking, outside of itself. Its activity of self-thinking thought is entirely inward. But it is love of this activity which sets the whole universe in motion. Or, more briefly, the Prime Mover is that upon which "the cosmos and nature depend." "Likewise the beauty queen does not do anything to compel the attention of everyone in a room. She simply is, and the intensity of her being shocks the senses of those around to attention. So, too, with the great work of art. Anyone who has visited the Louvre has no doubt seen the crowds around the Mona Lisa at all times. Though rather a small picture, it demands that those entering the room crowd about it in admiration. Thus the activity of the artist continues to draw viewers into a generic organization long after the work has been completed and the artist has died.

We should note, too, that just as the artist creates genera in particular acts of creation as well as in groups of creations through time, so does his work create particular observational genera with individual viewers as well as

\footnotetext{
${ }^{8}$ Thomas AQUinAs, Summa Theologica, trans. Fathers of the English Dominican Province. (New York, Cosimo, 2007), q.5, a.4, reply to obj.1.

${ }^{9}$ Aristotle, Metaphysics, trans. W.D. Ross, in The Basic Works of Aristotle, ed. Richard McKeon (New York, Random House, 1941), 1072 b 13.
} 
critical genera in response to his work. Different schools of thought will arise around an artist as they do around a philosopher or theologian, and this ought to serve as testament to the artist's ability to inform the imagination of the viewer in a variety of ways and to create organizational unity across several joints of reality.

\section{GENERA AND SENSE}

We have seen that genera arise between an artist and his subject as well as between the work of art and its viewer. Neither of these generic relationships is possible without the senses. For the painter can hardly paint an object unless he can see it - or at least see the materials he is working with, if he is talented enough to paint from memory or imagination. And a viewer certainly cannot appreciate a painting without the faculty of sight. In this sense, then, any artist, if he works without irony, advocates against the critical revolution implemented by Descartes.

Before Descartes, as Gilson reminds us in his work on Thomist Realism, there was little need to construct critical scaffolding for the senses. "After passing twenty centuries as the very model of those self-evident facts that only a madman would ever dream of doubting," Gilson begins his work, "the existence of the external world finally received its metaphysical demonstration from Descartes." ${ }^{10}$ Certainly the Aristotelian tradition takes it as obvious that the senses, though capable of deception under certain circumstances, are on the whole reliable informants about the nature of things. Plato, too, though he places greater intensity of being in the realm of Forms than in the realm of physical things, takes the evidence of the senses as more or less accurate. Descartes opened wide the doors to criticism of sense experience, with the embarrassing result, Gilson indicates, that even most modern realists have considered it necessary to make their realism critical. ${ }^{11}$

Here the artist often proves an ally to the philosophical realist, for again, if he takes up an unironic stance, the artist tends generally to take the evidence of the senses on good faith. Picasso, for instance, though ambivalent on metaphysical matters, creates in accordance with what the eye presents him. Whether in passion or in art, Picasso responds directly to the evidence

\footnotetext{
${ }^{10}$ Étiennne GILSON, Thomist Realism and the Critique of Knowledge, trans. Mark A. Wauck (San Francisco: Ignatius, 1986), 27.

${ }^{11}$ Ibid., 49-51.
} 
of the eyes. He recalls the famous judgment on Monet: "He is only an eye. But, my God, what an eye!"

Thus we see that the philosophical conservative, in his defense of the senses, might turn for an ally to even such a libertine as Picasso. We shall return to this point shortly, though we introduce it now as propaedeutic to the artist's subordination of the practical to the speculative. And here, in matters of speculation, we will begin to see the full power of Picasso's work as key to interpretation of art in its present state.

\section{SPECULATION AND THE BEAUTIFUL: ART COUNTER TO THE CRITICAL}

As our politicians grow younger and younger, we recall Aristotle's warning that politics requires prudence, and that the prudence required in the political realm is rarely to be found in the young. Likewise, as the climate grows increasingly political, the trend in the arts is to turn from art to propaganda, the distinction having been put to me once by an old Irish professor as that between the thing made to be beautiful and the thing made to prove a point.

Knowledge, again, may be divided into practical and speculative, with the practical issuing in some form of production and the speculative aiming at understanding for its own sake. We have drawn an analogy between the generic organization of knower-known and that of artist-subject. We must ask, though, whether art, like knowledge, can be divided into practical and speculative. Certainly all artistic activity results in some form of production, whether a painting, a song, or a sculpture, which reproduces an object of sense experience in a medium different from that in which it originally existed. Such production requires practical knowledge about how to hold a brush, how to mix colors, and so on, and in this sense the artist's work is practical. On the other hand, the great artist is the one who takes a kind of speculative delight in his subject. His work might almost be seen as a kind of practical coruscation of his speculative joy.

Moreover, we have already considered that the work of art, once produced, subsequently creates a generic organization between itself and the viewer, with aesthetic pleasure, itself directed to the ultimate goal of human happiness, as its organizational aim. The work of art, that is, properly understood, provides the viewer with insight into the nature of being by way of 
aesthetic pleasure. The beauty of the work, by its shocking goodness, compels the viewer to see some truth about reality and results in pleasure. The artist's productions, then, taken from the viewer's perspective, might more properly be viewed as speculative than practical in nature, despite the fact of their being physical productions.

\section{LES DEMOISELLES D'AVIGNON: THOMISTIC CONSIDERATIONS}

Our considerations thus far suggest three principles questions whereby we might approach St. Thomas's teaching on the problem of the one and the many and how that teaching might apply to the arts: (1) what is a genus, and how is it organized by contrary opposition?; (2) what role do the senses play in the generic organizations of knowledge and art?; and (3) how does the artist's work engage the mind of the viewer in the kind of speculative activity which tends toward human happiness? With these lines of inquiry as our guides, let us now turn to one of Picasso's best-known works, Les Demoiselles d'Avignon.

Picasso painted Les Demoiselles in 1907, though only after hundreds of preliminary sketches and studies. Five frightening cubist women, black-eyed and of indeterminate skin tone, gaze over a diminutive fruit-laden picnic blanket at the viewer. Other than this minor set-piece, there is little perspective in the work: the women might almost have been pasted in place, each from her separate frieze or hieroglyph or pediment. Indeed, the leftmost figure faces dead right as an Egyptian figure. Beside her two figures, though on plane with their fellows, appear to lie with hands behind their heads in bed, a sheet pulled lightly over their genitalia. And to the right, one peering out above the other, are two more ladies in masks apparently of African tribal design.

The work arises first from the artist-subject genus, and we begin our analysis there, with the subjects themselves. We know from the title, of course, that these are five women, and on first glance we intuit them to be women as well. Yet intuit we must, for the figures have undergone a cubist transformation whereby it is only certain geometric generalities rather than any anatomical particulars that key us in to the subjects' gender. Indeed, they are women, and from the title we might expect such gentle beauties as meet the eye in Botticelli's La Primavera. These ladies of Avignon derive, however, not from the Provençal locale but rather from a district of bordellos. 
Indeed, Picasso himself first called the work Le Bordel d'Avignon, and it was only a later curator who, from considerations of decorum, amended the title. These ladies gaze at us with anything but Botticelli's springtime sweetness. They either gather us in a blank, wall-eyed glance, or stare upon us as potential customers, or peer at us with such malice as to suggest that even across the medium of the canvas they might ensnare us with some Medusan evil.

These, of course, are the subjects as they appear to us, again, through the canvas. Who knows who might have inspired the work, though we might suppose from the title that they derived from Picasso's frequent visits to the brothel. There was, at any rate, a woman or several women with whom Picasso's mind engaged to produce the painting, and it is in the act of production that we see Picasso, like a general deploying his troops, passing his subjects through his internalized record of the artistic tradition, and in the painting's allusive properties and technical elements we see, as it were, the artist's strategy laid out.

We have mentioned in passing several of those influences apparent in the work. The leftmost figure recalls Egyptian art, the two on the right African art. The general grouping recalls, at a mythic and moral distance, La Primavera, as well, more recently, as compositions by Matisse, Cezanne, Gaugin, and El Greco, the latter two having cast an especially strong influence over the Malagan's imagination. The bold gazes on the ladies' faces remind us, too, of Manet's Olympia.

Likewise in terms of technique we see Picasso shifting first one way then another to best serve his artistic purposes. On the one hand, by his allusions and his disregard for perspective, he takes us back to the world of primitive art. On the other, his cubist figures draw us to his own historic context, one in which art is moving away from traditional forms of representation and in which society is losing its sense of those fundamental metaphysical principles whereby the rest of life, from the production of art to the organization of the family, is directed most effectively to the end of human happiness.

So we see that between the two generic poles of subject and artist lie a host of internalized considerations whereby the artist, directing the genus toward its end in an actual work of art, decides how to deploy his powers to the greatest effect. The relation between artist and subject is not, properly understood, one of immediacy, but one mediated by an understanding of artistic tradition and the artist's own powers.

This last point bears repeating, for it reminds us that the artist's job is not simply to copy exact on canvas what he has seen in life. If it were so, then 
art would become an athletic contest of hand-eye coordination, and the greatest artist would be simply the one who most nearly approximated the work of the camera.

But the human eye is not simply a camera, no plain recording device intended to transmit images to the brain. Rather, it is the first gauge whereby we coordinate our responses to the things of the world. I see brake lights on the highway ahead and move my foot accordingly. While walking down the street I see a man in a clown suit playing the tuba and stop to watch for a moment. The artist sees a woman or a seascape and becomes filled with desire to produce a corresponding work. In the process he employs tradition and technique according to his psychological state and the demands of his medium.

It is curious to note, though, that the procedent work of art often does not burst forth entire from the mind of the artist like Athena from Zeus's skull. For the artist serves also as his own first audience, and it may be that he passes through several versions of a work before finding that one which satisfies his internal vision. That is, it may take multiple attempts for the subject-artist genus to reach its intended end. Again, Picasso spent nine months and hundreds of sketches in the production of Les Demoiselles. And in this we see another similarity between art and knowledge. For knowledge, according to St. Thomas, is not something we gain, save in mystical circumstances, in a flash of insight, but rather occurs by a long process beginning in the senses and passing into the mind by way of the imagination. We learn, for the most part, slowly, and perhaps this is why human beings are meant to live to seventy or eighty years, that this is the time it takes to become what we are meant to be. The lives of artists often evidence this abundantly. Picasso, through his very lengthy life, was ever expanding his artistic vision, ever attempting to work in new media, ever looking at things anew and measuring the new vision against that garnered earlier. We watch as in his early years he paints scenes of life in Malaga and imitates the Spanish masters and religious painters, then later as he passes through the Blue, Rose, and Cubist periods, and still later as he sculpts on a grand scale and produces volumes of poetry. The world rushes in upon his eyes and compels him to gather up the products of his sense faculties into new genera.

In this process of creation consequent upon sense experience, we begin to see an avenue whereby art might lead philosophy to a renewed understanding of the importance of a critical stance. The artist is critical, but his critical movement does not begin with the facts of sense experience. He takes, as do 
most sane people, the evidence of his senses as a real ground on which to establish the rest of his work. It is in the process of imagination that his work becomes critical. In Les Demoiselles, for instance, Picasso's cubism springs from an imaginative action of deconstructing the human figure and then reconstructing it in a variety of shocking forms. On one level, this technique might be viewed simply as a reminder to the viewer of the particularity of human being - the way in which the human sense faculties depend on the way the human body has developed. In the leftmost figure, for instance, whose right eye alone is visible to us, we are reminded of Ishmael's reflections in Moby Dick on the vision of the whale, with each eye separated from the other by the mass of the head. ${ }^{12}$ What would it be, Picasso seems to ask us, for human beings to see in such a way, or for our bodies to be reduced to a geometry of parts capable of assembly in a variety of ways?

Once the senses have obtained material for reflection, that is, the artistic imagination may go to work on it, not only raising such questions as we have mentioned on the design of the human organization but also employing memory and habit to create an artistic context in which a work might be considered. When we remember, for example, the amount of time Picasso devoted to the creation of Les Demoiselles as well as the number of artistic influences present within the work, we surmise that it was from a need to see just how all those influences might best fit together to carry out the work's organizational aim that Picasso spent so much time in its preparation.

No doubt, however, artists could care little for such elements of their work were it not for the fact of their being organized with an audience of some kind in mind. It was only by viewing the works of Gaugin, Matisse, El Greco, and Manet that Picasso could internalize them and in turn direct them toward the organization of his own work, an organization which must in part be directed to those artists, critics, and ordinary viewers to whom the work might speak. And with this we come to our consideration of the artist's power to engage the viewer in the kind of speculative activity which leads to human happiness.

For a work of art, in a certain sense, might be deemed one of those strange parts of human life which is at once most useless and most precious. Humans have no material need for art as they do for food, water, and shelter. A painting can serve as none of these. Nonetheless, there is in a painting the kind of excess which mirrors the faculties of the human person. That is,

\footnotetext{
${ }^{12}$ Herman Melville. Moby Dick, Billy Budd, and Other Writings (New York: Penguin Putnam, 1983), 376-77.
} 
there would seem to exist no bodily need for the sight of a sunset to result in pleasure, but such a result seems universal to human experience.

The artist, by his sense acuity and his ability to translate experience into art, guides the sense and the imagination of the general populace, or at least to those whose sense and imaginative faculties are attuned to artistic experience by temperament or education. And, as mentioned before, it is through the experience of the work of art that the viewer and the art, as well as the mind of the artist, are drawn into an organization, one whose aim is not production but rather speculation on nature - on the way the cosmos and its constituents are structured as well as on the way that the viewer himself relates to that overall structure.

In Les Demoiselles, again, the viewer is drawn, rather shockingly at first, into reflections on the nature of woman. Is she to be taken primarily as subject of ancient sculpture and hieroglyphs, a paragon of beauty to mark human bodily aspiration? Is she fertility goddess, reclined and waiting, by the desire she inspires, to bear humanity on its way through time? What masks does society place upon her, and which does she raise to her eyes of her own accord? How has her being shifted as a result in paradigm shifts within society and the family? Picasso, by way of his own wonder, draws us to wonder as well, not for the sake of producing anything, but simply to understand the contours of human being. We are drawn into the genus of the painting, and by its organization, we are directed to the genus of being as a whole.

\section{NOTES TOWARD A GENERIC METHOD OF ART}

In all we have said on the problem of the one and the many and the way the artist fits into such considerations, we must remember that each of those smaller genera we have considered, from a molecule to a human being to a work of art, exists not as a genus unto itself, but rather as a part within the genus of being as a whole. This understood, we wish to conclude with a reflection on the role of art within this genus as it relates to the end of the human being.

A work of art, we have noted, exists as a kind of nexus of the artist's speculation issuing in a productive end along with a viewer's sense activity leading into speculation. Human beings, Aristotle teaches, are directed to the end of happiness, and happiness, he says, lies in the kind of contemplative 
activity which the Prime Mover experiences. ${ }^{13}$ St. Thomas, generally speaking, follows Aristotle here, though with Revelation as guide, he indicates that the happiness toward which humans are directed lies not simply in the contemplative activity of an impersonal Prime Mover but rather in the contemplative experience of the love of the personal Triune God.

In any genus, we have noted, the parts are arranged by contrary opposition according to each part's possession of the organizational aim. This being the case, we can suppose that the greatest works of art will be characterized by a simplicity of composition whereby with the least variety of parts they will contain both the greater intensity of being and greater intensity of inspiration. Moreover, if art acts as stimulus to speculation on the nature of being, then that art would seem best which most nearly approximates being and which best directs the viewer to his end.

We must note, of course, that to approximate being is not simply to achieve sense realism. Les Demoiselles could hardly be said to approximate with any degree of closeness our sense experience of women. Nonetheless, it captures in just five figures some of the complexity of woman and her place in the shifting cultural and social landscape Picasso lived in and in which we continue to live. In doing so, the painting not only forms its own organizational whole but also directs the viewer to reflection on the broader genus of man and his place in the totality of being.

For St. Thomas, as for Aristotle, it is that which accomplishes most with the least effort that has the greatest virtual quantum intensity. The Sun supplies life, as a proximate cause, to all of earth simply by the act of fusion on which it lives. The general, by imparting the strategy in his mind to a few subordinates, directs the activity of countless individual men toward the goal of victory. And at the cosmic level, God directs the entirety of the universe to himself simply by "that love which moves the Sun and other stars."

Now, if all of the genus of being is directed to God as its end, it follows that those particular genera possess the greatest virtual quantum intensity which best approximate in their direction the overall aim of the universe. And in this we may find a guide for artistic activity, that the artist should seek in his work to approximate that tendency of all being toward its source and end in God. This is not to say that all art should be explicitly religious, certainly not that it should contain some moral instruction, though art,

\footnotetext{
${ }^{13}$ ARISTOTLE, Metaphysics, 1072 b 15.

${ }^{14}$ Dante. The Divine Comedy: Paradiso, trans. John D. Sinclair (New York: Oxford, 1939), XXIII, 145 .
} 
equivalent in scope to all of human experience, ought to be able to accommodate such elements without difficulty. The artist who is attuned to the end of all being, though, will most easily pierce the hard rind of daily sense experience and with the least effort create that virtual quantum intensity within his work as to satisfy his own vision and direct the mind of the viewer to the same vision. For the end of all human activity, whether productive or speculative, is human happiness, that which in the end exists for no aim other than itself. To this let all wonder lead us, even that wonder beginning in the strut of a pigeon in the street. From such simple points of entry may arise access to the end of all human being, led by the Dove to that vision of which all great art is but a poor preliminary shadow and in which each human soul is intended as a brush stroke.

\section{BIBLIOGRAPHY}

Aquinas, Thomas. Commentary on the De Trinitate of Boethius. Translated by Fathers of the English Dominican Province. New York: Cosimo, 2007.

AQUinAs, Thomas. Summa Theologica. Translated by Fathers of the English Dominican Province. New York: Cosimo, 2007.

Aristotle. Metaphysics. Translated by W.D. Ross. In The Basic Works of Aristotle, edited by Richard McKeon. New York: Random House, 1941.

Dante. The Divine Comedy: Paradiso. Translated by John D. Sinclair. New York: Oxford University Press, 1939.

GiLsON, Étienne. Thomist Realism and the Critique of Knowledge. Translated by Mark A. Wauck. San Francisco: Ignatius Press, 1986.

Homer. The Odyssey. Translated by Richmond Lattimore. Chicago: University of Chicago Press, 1965.

Melville, Herman. Moby Dick, Billy Budd, and Other Writings. New York: Penguin Putnam, 1983.

O'Rourke, Fran. Pseudo-Dionysius and the Metaphysics of Aquinas. Notre Dame, IN: University of Notre Dame Press, 2005.

Plato. The Republic. Translated by G.M.A. Grube. In Plato: Complete Works. Indianapolis: Hackett, 1997

Richardson, John. A Life of Picasso: The Prodigy, 1881-1906. New York: Alfred A. Knopf, 2012. 


\section{BELLOWS IN MALAGA: \\ THOMISTIC INSIGHTS VIA PABLO PICASSO}

\section{S u m m a r y}

The paper begins by clarifying St. Thomas's teaching on the problem of the one and the many by answering three questions: 1) What is a genus? 2) How are genera organized according to contrary opposition, and what role does virtual quantity play in such organization? 3) How do a knower and the thing known constitute opposite poles of a genus? With these answers firmly in hand, we then turn to an analysis of art, with particular reference to Picasso, with a view to clarifying three complementary points: 1) How the artist and his work constitute a genus, and how the work of art and the viewer constitute a genus; 2) How the work of art affirms the generic relation of sense object and sensate being; 3) How the artist subordinates the practical to the speculative in his work and what this implies for the role of the artist in an increasingly practical age.

Key words: Aquinas; genera; contrary opposition; Picasso; organization; one and the many.

\section{MIECHY W MALADZE: \\ TOMISTYCZNY OGLĄD NA PODSTAWIE PICASSA}

\section{Streszczenie}

Artykuł rozpoczyna się od wyjaśnienia nauczania św. Tomasza na temat problemu ‘jedno i wiele' poprzez udzielenie odpowiedzi na trzy pytania: 1) Co to jest rodzaj? 2) W jaki sposób, na bazie przeciwieństw, zorganizowane są rodzaje i jaką rolę odgrywa w takiej organizacji ilość wirtualna? 3) W jaki sposób poznający i to, co poznawane, stanowią przeciwstawne bieguny danego rodzaju? Bazując na odpowiedziach na te pytania, przechodzimy następnie do analizy sztuki, ze szczególnym uwzględnieniem Picassa, w celu wyjaśnienia trzech uzupełniających się punktów: 1) W jaki sposób artysta i jego dzieło stanowią rodzaj i w jaki sposób dzieło i odbiorca stanowią rodzaj; 2) W jaki sposób dzieło sztuki potwierdza rodzajową relację zmysłowego przedmiotu i zmysłowego bytu; 3) W jaki sposób artysta podporządkowuje to, co praktyczne, spekulacyjne, swojej pracy i co to oznacza dla roli artysty w epoce coraz bardziej nastawionej na praktyczną stronę życia.

Słowa kluczowe: Akwinata; rodzaj; przeciwstawna opozycja; Picasso; organizacja, jedno i wiele. 